Delft University of Technology

\title{
The Challenge of the Dutch Port-City Interface
}

A. Daamen, Tom; Louw, Erik

DOI

10.1111/tesg. 12219

Publication date

2016

Document Version

Final published version

Published in

Tijdschrift voor Economische en Sociale Geografie

\section{Citation (APA)}

A. Daamen, T., \& Louw, E. (2016). The Challenge of the Dutch Port-City Interface. Tijdschrift voor Economische en Sociale Geografie, 107(5), 642-651. https://doi.org/10.1111/tesg.12219

\section{Important note}

To cite this publication, please use the final published version (if applicable).

Please check the document version above.

Other than for strictly personal use, it is not permitted to download, forward or distribute the text or part of it, without the consent of the author(s) and/or copyright holder(s), unless the work is under an open content license such as Creative Commons.

\section{Takedown policy}

Please contact us and provide details if you believe this document breaches copyrights.

We will remove access to the work immediately and investigate your claim. 


\title{
THE CHALLENGE OF THE DUTCH PORT-CITY INTERFACE
}

\author{
TOM A. DAAMEN \& ERIK LOUW \\ Faculty of Architecture and the Built Environment, Delft University of Technology, Julianalaan 134, \\ 2628 BL Delft, the Netherlands. E-mail: t.a.daamen@tudelft.nl; e.louw@tudelft.nl
}

Received: November 2014; accepted June 2016

\begin{abstract}
This paper explores the shifting geography of the port-city interface in The Netherlands since the mid 1970s, and assesses its current scene. With an eye on port-urban governance and planning, we provide a dynamic account of the forces that have played a major role in the implementation of waterfront redevelopment schemes in Amsterdam and Rotterdam. Our account shows that the power balance between the port authority, the municipal planning office, and the users of the port has shifted. This has compelled urban planners in both port cities to adopt a more incremental waterfront development strategy than they had anticipated, and has given port users more influence on the plans for the current port-city interface.
\end{abstract}

Key words: Port-city interface, waterfront development, governance and planning

\section{INTRODUCTION: THE DUTCH PORT- CITY INTERFACE REVISITED}

As the waterfront revitalization phenomenon has become increasingly widespread in geographical terms, it has attracted the attention of numerous academic disciplines [...]. Geography has played, and continues to play, a leading part in these debates - a good measure of interdisciplinary cooperation is long apparent. (Hoyle 2000, p. 402)

Since its emergence on the United States's East coast in the late 1950 s, waterfront regeneration projects have spread to port cities all over the globe. The dispersion has changed the face and frontier of many of the world's largest seaports, although many inland harbours and quays have seen similar transformations. Nowadays, few places more extreme with regard to the complexity involved in reworking seaport structures into a high quality urban environment. While the revitalisation of portindustrial waterfronts have been termed a worldwide urban success story (Breen \& Rigby 1996), only a small amount of the world's waterfront projects have been widely accepted as both economically beneficial and socially just. In fact, the resources and institutions necessary to lead and direct meaningful waterfront change prove significantly hard to mobilise - particularly in seaport cities.

Leading planning scholars have repeatedly pointed to Dutch practice as one of the exceptions, being able to deliver wellbalanced urban environments (e.g. Healey 2010; Fainstein 2011). A recent contribution to the Windows on the Netherlands section focused on the dynamic geographies of global commodity trade, linking and comparing the geography of commodity finance to that of the production and distribution of 
goods in Rotterdam and Amsterdam (Jacobs 2014). We take the same cities into consideration, but focus on the local redevelopment of the port-city interface and add a spatial planning and governance perspective to our geographical understanding of these two Dutch port cities. In Rotterdam and Amsterdam, spatial and functional waterfront change has signified and shifted the geography of the port-city interface for decades. This paper provides an analysis of the shift's current position and state.

\section{UNDERSTANDING THE CHANGING PORT-CITY INTERFACE}

Urban designers have termed waterfront regeneration an effort to reclaim the city's 'abandoned doorstep' (Bruttomesso 1993), while geographers and social scientists have put the phenomenon forward as places of capital accumulation and consumerism (Harvey 1990; Norcliffe et al. 1996). Planners have more recently framed projects in the port-city interface as tangible expressions of neo-liberal tendencies in the sphere of urban governance (Marshall 2001). Indeed, the projects that signify the geographical retreat of the port from the urban core are magnified intersections of urban forces driving up political and economic stakes (Malone 1996). As Hoyle had already argued in 2000, urban governance and planning play a key role in this process: the motives for waterfront development initiatives may be more easily found among planners, than in the port migration process that occurred up to the 1980s.

Today, planning prospects of an autonomous retreat of the port from waterfront sites - creating ample opportunities for urban regeneration - are often flawed. Port withdrawals from the city can no longer simply be seen as a logical outcome of technological innovations (i.e. containerisation, larger vessels), the rationalisation of port operations, and the availability of alternative locations. The forces that shape geographical shifts in the port-city interface have become much more complex, and are better explained from an institutionalist point of view: a view that attends to the rules, norms, and beliefs that govern the policies and plans for city and port, without neglecting the ever-changing behaviour and capabilities of those affected by the port and port-related projects (Daamen \& Vries 2013; Notteboom et al. 2013).

The once symbiotic relationship between the city's economic leaders and its mercantile port has evolved into something that may be described as a business affiliation gone cold. Hence it is often conflict, especially in port cities with economically still vital port operations (as Amsterdam and Rotterdam), that characterises interaction when port city authorities are planning the development of waterfront zones - also in the Netherlands (Wiegmans \& Louw 2013). While Hayuth (2007) still recognised that port and city authorities share some common economic goals, a more recent report by the OECD (2013) suggests that such common goals have become increasingly hard to define. Indeed, many European port cities are at the stage of considerable debate about whether the widely dispersed economic benefits of port operations are enough to outweigh their largely local negative impacts (OECD 2013).

The OECD (2013) report and other port research publications (e.g. ESPO 2010) suggest that the contemporary port-city interface is beset by efforts to 'renew the relationships' between these two drifted entities (Hoyle 2000; Hall, 2007; Ducruet et al. 2011; Jacobs et al. 2011; Hall \& Jacobs, 2012; Ng et al. 2014). In this paper, we analyse the geography of this renewed relationship in the port-city interface of Amsterdam and Rotterdam. Both cities have substantial ports, and operate within the same national institutional environment. What differs is their more local institutional geographical environment, which makes them ideal for a comparative case study. The analysis is based on previous work of the authors (Daamen, 2010; Wiegmans \& Louw, 2010) on Rotterdam and Amsterdam respectively, and an additional review of recent planning documents.

\section{SHIFTING PORT-GITY GEOGRAPHIES IN ROTTERDAM}

The Meuse River is widely understood as the defining element of Rotterdam's geographical evolution. In the 1970 s, the river divided 
the city's port-industrial, proletarian south bank from its socially and economically more varied city districts north of the river (McCarthy 1996). The city centre had been largely rebuilt after its Second World War devastation, but was still cut off from the river because old port terrains beset the waterfront. During the course of the next three decades, this picture changed as Rotterdam developed and implemented two ambitious frameworks of waterfront interventions.

For municipal planners and city marketers, Rotterdam's Waterstad plan was to bring back the river into the hearts and minds of its inhabitants. Planners and urban designers in Rotterdam had become increasingly aware of the attractiveness of old quays and waterfront structures, taking internationally renowned projects such as Baltimore's inner harbour as an inspiring benchmark (Teisman 1992). They thus proposed to restore the link between the inner city and the river through a number of port-urban transformations. The city planners defined these transformations as opportunities to slow down the outflow of middle and highincome groups towards the city's periphery, providing ample space for the settlement and growth of new economic functions in the upcoming business services sector of the economy.

In Rotterdam, the dominance of socio-cultural policies during the 1970s resulted in the development of large inner-city social housing estates, often at the expense of economic functions that were more or less removed from the city's inner city and old waterfront locations (Van der Knaap \& Pinder 1992). As unemployment rates surged, the intricate relationships between the sociocultural well-being and economic vitality of the city became dramatically apparent (Priemus 2001). Around 1980, it became clear that turning things around in Rotterdam would demand a delicate mix of ambition and pragmatism - a mix that resonated well with the vigilant debates among planners and urban designers in Rotterdam at the time (Meyer 1999).

While the first municipal waterfront programme focused mainly on waterfront areas north of the Meuse in the economically difficult early 1980s, Rotterdam's planning ambitions made an important leap during the years of economic recovery after 1985 . Municipal plans now proposed to bridge the physical and psychological barrier between the north and south bank of the river. A new bridge was to become a defining element in the social and economic revitalisation of the river's south edge and a significant part of Rotterdam South's most dilapidated districts. It was also meant to provide an important starting point for the realisation of an area-based masterplan called Kop van Zuid. The initial plans for this project projected a programme of about 4,500 residential units, 400,000 sqm of office space, and 95,000 sqm of other functions onto a total area of 125 hectares (Wigmans 1998).

Combined with a new subway line, the new Erasmus Bridge from the inner city to the Kop van Zuid would greatly improve the accessibility of the deprived parts of town from the Northern part of the city. It increased the attractiveness of the waterfront for new living (apartments), working (offices), and leisure oriented property development (hotels and theatres). Spatial planners and policy-makers started to favour such mixed-use development, as they realised the importance of integrating residential, employment, and welfare functions in the same local environment (Van der Knaap \& Pinder 1992). The 'entrepreneurial' character of this approach was spurred by national government policies, which prospected financial contributions to collaborative, specifically publicprivate partnership schemes (Taşan-Kok 2010).

The Dutch Ministry of Spatial Planning adopted the Kop van Zuid project as one of its so-called 'key projects' in their 1990 brief. ${ }^{1}$ The inner city of Rotterdam, as well as those of several other Dutch cities, had to become the focal points of a strong economic region. However, although the national key projects propelled the pursuit of the urban economic restructuring desired, it also stimulated an intra and inter-urban competition. City authorities competed fiercely with each other in order to attract international business corporations and other economic activities to their respective territories (Wigmans 1998). Within Rotterdam, planners focusing on the redevelopment of the city's main railway station area also had similar target groups in mind (Teisman 1992).

Ultimately, the Kop van Zuid project's office programme would have to be downsized and adapted several times during the 1990s and 


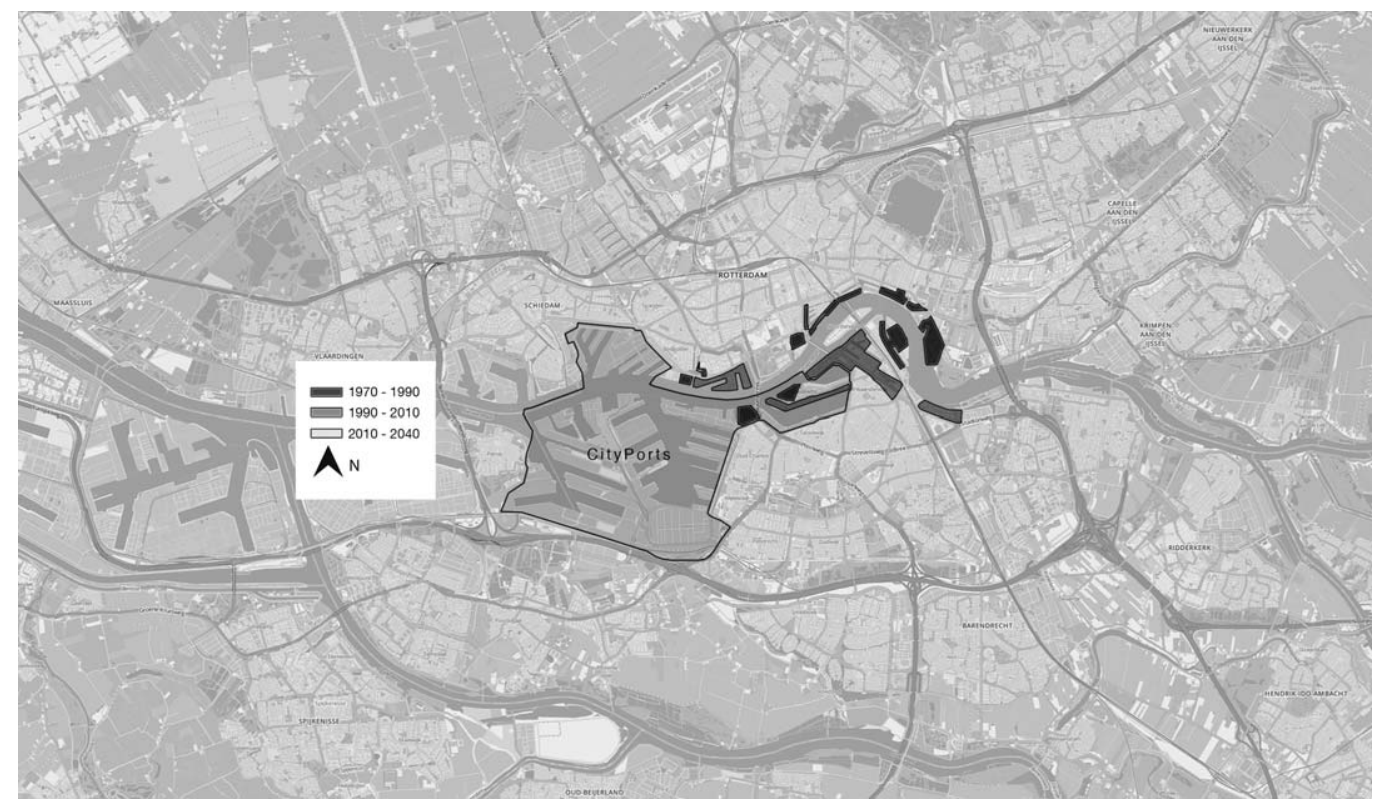

Figure 1. Waterfront development areas in Rotterdam since the 1970s.

$2000 \mathrm{~s}$ - particularly into residential functions. Although the municipality and involved private investors wanted to prevent the image of a 'civil servant pier', the project's pivotal Wilhelmina Pier nevertheless became the home of many public bodies and non-profit organisations, including the now corporatised port authority, and, more recently, the larger part of the municipal organisation.

Towards the end of the 1990s, new waterfront development schemes were implemented on the North banks farther East of the Kop van Zuid project. Here, attempts to attract new economic clusters to Rotterdam also largely failed. The piers around the Sint Jobshaven have nevertheless become a relatively mixed residential area close to what are still largely deprived social neighbourhoods.

Despite the difficulties experienced in the redevelopment of the older and more centrally located port terrains in Rotterdam, a new framework was drawn up for the remaining port areas within the city's highway rim. If the municipality was going to support the extension of the port into the North Sea, the port authority had to agree to deliver its terrains back to the city as soon as they became derelict or otherwise eligible for urban redevelopment
(Daamen 2010). In the decade since the formal start of the so-called Stadshavens, or CityPorts project in 2004, several locations within this 1,600 hectare area have been redeveloped (see Figure 1). However, the port authority managed most of the projects in the CityPorts area after a joint port-municipal development company failed because of the still very viable port operations that largely beset the area. The relocation of port functions necessary for redevelopment to occur has only been piecemeal, either due to cost or the lack of alternative locations. This, and the dramatic effects of the 2008 financial crisis and subsequent economic downturn, has forced Rotterdam to redefine the CityPorts project and adopt what is in fact a very incremental and fragmented development strategy - a strategy that brings specific plots and locations into development as existing lease contracts end and new market interests emerge.

\section{PORT-URBAN TRANSFORMATIONS IN AMSTERDAM}

Amsterdam's history in large-scale waterfront transformations started in the 1980s, when the municipality adopted a 'compact city' 


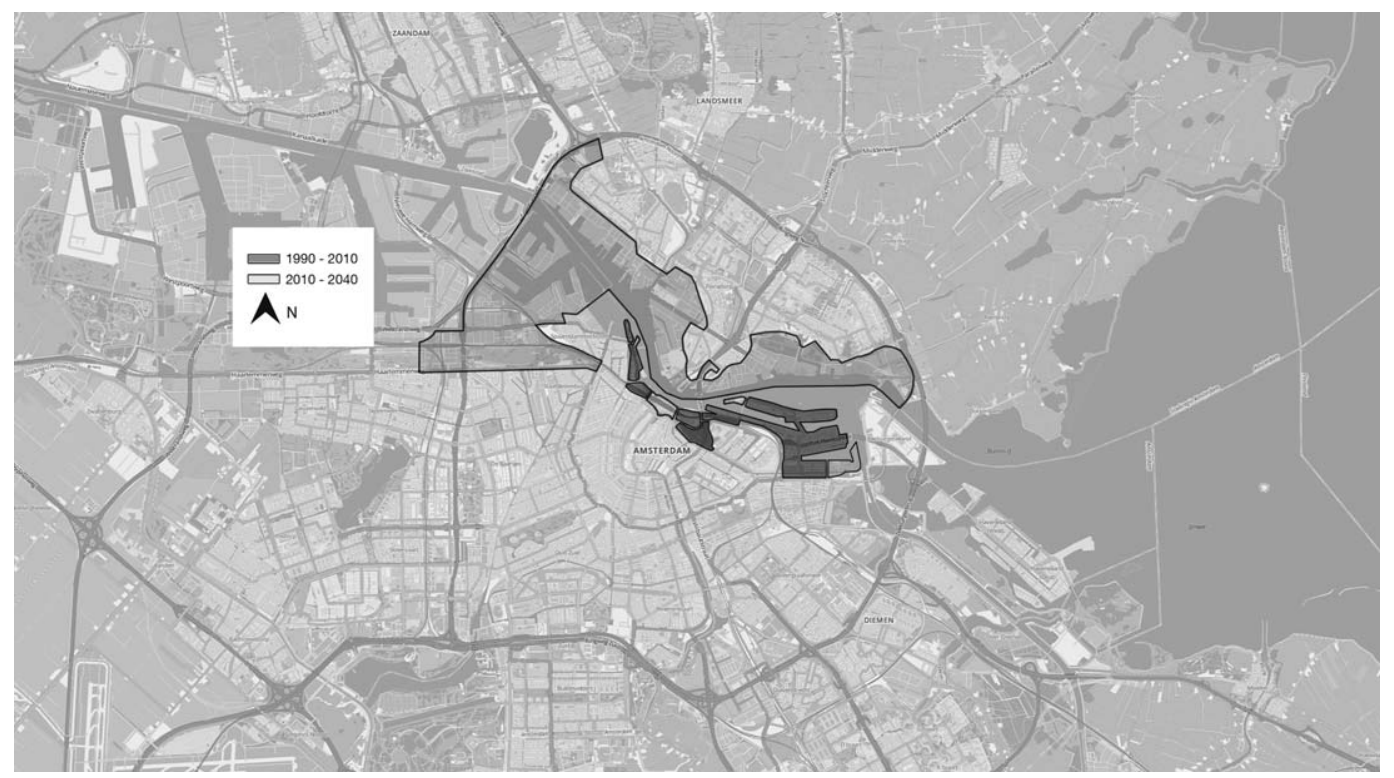

Figure 2. Waterfront development sites in Amsterdam since the 1970s.

policy and developed the first plans to transform the port-industrial zones along the river IJ. The IJ embankments East of Amsterdam's main railway station - itself a symbol of the city's alienation from the IJ - were meant to become the city's main office location, while the closest Eastern docklands were planned as a mixed use area (see Figure 2).

One of the main purposes behind making the Eastern IJ banks an office location was to boost the economic function of the inner city, and to rectify the increasing unbalance caused by the southbound shift of economic activities in the service sector (Ploeger 2004). One of the main guidelines was to improve the relationship between the (historic) inner city and the IJ embankments by creating public attractions with sufficient appeal and increasing the accessibility between both areas; to develop, where possible, the typical inner city uses which because of their scale and accessibility requirements are difficult to fit into the [historic] inner city morphology; and to create the linkage of the [historic] inner city to the IJ embankments' (Witbraad \& Jorna 1993, p. 232).

In the beginning of the 1990s, it became clear to city planners that the Eastern IJ banks would never reach the status of
Amsterdam's central business district (CBD). The most prestigious firms in the service sector favoured the so-called Zuidas or South Axis location between the city centre and international airport Schiphol. Also, the political climate changed in favour of a housing-oriented development in the whole of the Eastern docklands area, which was also given the status of key project. In the same period, the development of the mainly residential Java and KNSM islands as well as the docklands farther East was well underway. Around 1987, the first apartment buildings were delivered in these areas. Initially, this mainly consisted of affordable housing, but private residential development would soon gain the upper hand.

Between 1987 and 2005, housing corporations, property developers and large contracting firms built a total of around 9,500 units in the Eastern dockland areas (e.g. Hoppenbrouwer \& Louw 2005). After the year 2000, the areas of the older Eastern Trade Quays closer to the city centre were also set for development. Morphologically, this development resembles the earlier CBD-plans quite closely, but functionally there was a shift towards a larger portion of residential functions. Nevertheless, closest to the central station, a cruise 
ferry terminal and a music theatre were built on these quays - attracting tourists as well as Amsterdam residents who rarely visited the waterfront of their hometown.

Due to high economic growth, Amsterdam faced a great demand for housing from the mid 1990s onwards. This means that planners and developers were in search for new locations for residential development. Increasingly, they looked westwards to harbour areas. In contrast to the Eastern docklands, which had almost lost its harbour activities in the 1980s, the harbours just West of the station were still in use. Additional plans for at least another 5,000 houses in the parts of the port close to the city (Houthaven and the former NDSM wharf) were developed in the 1990s and at the beginning of the millennium. These plans are more problematic and controversial than the Eastern docklands and IJ banks. De Roo (2003, p. 306) analysed the conflict between spatial and environmental planning for the Houthaven, and concluded that the planning process had ended in a 'stalemate', particularly because most of the proposed dwellings were planned in a zone in which residential development is restricted because of noise pollution. ${ }^{2}$

Eventually, in 2008, the municipality and three companies who were based in the port settled that, under certain conditions, residential development in the Houthaven and NDSM wharf area would be allowed. However, they also agreed that in the coming 20 years, the municipality would not approve any new residential developments that could harm the companies' freedom to operate. This agreement meant that after 2028, new developments can become a possibility. Hence, the municipal spatial planning department and the port authority have already performed scenario analyses on the port-city interface between 2030 and 2040 (Gemeente Amsterdam 2013). These analyses are part of a so-called transformation strategy and foresee up to 20,000 residential units in current port areas.

Initially, planners in Amsterdam were mainly interested in the southern side of the IJ. The Northern IJ banks, beset by industry and shipyards, were intended to continue their port-industrial use. Up until the late 1990 s, there was no clear vision about the future of these areas. This changed when the oil company Shell, one of the main land users, contacted the municipality about their plans to restructure its laboratories situated in a prime location right across the water from the central station. Shell also alluded that it had no objections against residential development in the area. This move by Shell is considered a main turning point in the thinking of the Northern IJ banks (Dembski 2013). The first masterplan announced that about 9,000 residential units and commercial spaces for 25,000 workplaces would be built on the Northern banks of the IJ. In 2007, the construction of the first houses in the area called Overhoeks had started. In order to attract a wider public to the area, a film museum has been built, which features as a waterfront icon. For Shell, a new technology centre encompassing 81,500 sqm was completed in 2009. The company's old office tower is being retrofitted into a multifunctional tower on the waterfront.

Compared to the development of the Eastern docklands, the development of the Northern IJ banks is planned less rigidly. This is because the total development area is quite expansive, and there are still various firms along the IJ that cause environmental threats to residential development and cannot be moved elsewhere cheaply. Induced also by fragmented land ownership, the municipality therefore favours an incremental transformation process. This step-by-step strategy allows for negotiations with sitting landowners, which enables the port-urban transformation so desired, but also slows down its pace.

\section{CHANGING FORCES IN THE DUTCH PORT-CITY INTERFACE}

On 1 April 1 2013, the hitherto municipal port authority of Amsterdam was officially 'corporatised' into an independent, though publicly owned limited company. The contracts signed in Amsterdam did not, however, include the legal transfer of port terrains from the municipality to the new port authority. Instead, all port-industrial terrains were placed under port control through a perpetuate lease agreement free from rent. 
On top of that, all port areas within Amsterdam's main highway rim were designated as eligible for 'transformation into work-living environments' - though no sooner than the year 2025 (Gemeente Amsterdam 2013). A relatively small part of this area, the Minervahaven, is in the process of transformation by replacing port functions with creative and leisure industries. In contrast to Overhoeks, the port authority is in the lead of the incremental transformation process in this area, which 'forms a buffer between the residential area of the city and the heavier industry in the rest of the port'. ${ }^{3}$

Similar to agreements made in Rotterdam for the corporatisation of its port authority nine years earlier (Daamen 2010), it was recorded that the city council in Amsterdam would retain a firm grip on the port's landuses in three ways. First and foremost, the municipality would retain its ownership and legal status as main leaseholder of all port lands. Second, several public law instruments would guarantee the powers of the city to decide over port land-uses. Third, the municipality would be able to influence the port authority's strategic decision-making through its statutory powers as chief - and as of yet only - stockholder (Haven Amsterdam 2013). These three points answered some of the concerns raised in the city's planning community about the development of politically or socially undesirable land-uses in the Port of Amsterdam, and probably eased some of the worries of those who associated the corporatisation more generally as a weakening of municipal control over the port's evolution.

The formal institutional changes in Amsterdam and Rotterdam resonate well with the process of port authority corporatisation that has been progressing all over continental Europe, and to a significant extent, the entire world (Verhoeven 2006; World Bank 2007; Ng \& Pallis 2011). A crucial aspect of this process is the treatment of port property, as next to port dues, land leases are a port's main source of income. In these Dutch cases, the choice to transfer municipal control over port assets to a new entity through perpetuate lease has its advantages. One is that it does not involve full transfers of ownership, which prevents the state from imposing property taxation. Another advantage is that it provides the municipality the opportunity to keep exerting some sort of control over assets through its status as main leaseholder. And moreover, it allows for a relatively swift withdrawal of these assets from the port as terrains become 'fit' for porturban transformation. Or does it?

Recent empirical observations in Rotterdam show that, although it was agreed in 2004 that the new port authority would transfer its control over the destiny of certain terrains in the CityPorts area, large-scale transfers have yet to emerge In spite of new agreements in 2007 and an ambitious municipal structuurplan for the area in 2011, new investments and spatial changes in Rotterdam's current port-city interface have been executed only piecemeal, and under strict port authority supervision. The fact that some of these new projects concern non-port uses is more likely explained by port authority pragmatism, than by the municipal capacity to enforce its planning ambitions.

\section{CONGLUSION: A NEW CHALLENGE}

The relative success of [waterfront redevelopment] will depend essentially on three things: integration, integration, and integration. First, integration of past and present; second, integration of contrasting aims and objectives; and third, integration of communities and localities involved. (Hoyle 2000, p. 415)

In his study on the complex decisionmaking around the waterfront project of Kop van Zuid in Rotterdam, Teisman (1992) retraces a municipal brief to retain the south edge of the Meuse for port uses in 1969, only to be cast aside by the city council two years later. The council decided to revise its earlier view that the southern edge of the river could retain its port-industrial land uses, and that 'the river should be given back' to the city (Teisman 1992, p. 187). This ambivalence about of the areas that signify the port-city interface has continued to characterise Rotterdam's policies and plans 
since. This has often spurred uncertainty and frustration among port users, and has fostered speculation and strategic behaviour among those who aim to profit from potential land-use revisions (Daamen 2010; Milošević 2014). While the most recent Port Vision 2030 reconfirmed that parts of the CityPorts area are still set to undergo a porturban transformation, it stresses economic development and refrains from statements about residential uses - uses that do feature the 2011municipal structuurplan for the area.

In the period since the 1970s, planning ambitions for the port-city interface in Amsterdam have been much more consistent. Although municipal planners in both port cities had to perform similar revisions to their plans during implementation -converting plans for commercial offices into residential land-use designations - Amsterdam has been able to fall back on a relatively stable demand in its housing market and thus continue the implementation of its waterfront plans. It is only recently that powerful port users have taken a stand against the waterfront ambitions of Amsterdam's land development office. Although agreements between the municipality and the now independent port authority have been signed, it remains to be seen if the last port terrains inside Amsterdam's main highway rim will indeed be transformed into more 'workliving' uses. The tradition in Amsterdam of long term strategic planning indicates that this transformation eventually will take place.

In both Amsterdam and Rotterdam, a shift from a plan-led transformation to an incremental transformation process occurred. Although this inclines to site-by-site partnership-based forms of (hybrid) governance such as those found by Oakley (2011) and Galland and Hansen (2012) - this has hardly been observed in Amsterdam and Rotterdam. One explanation for this is a strong belief in strategic planning within the two largest Dutch municipalities, although our evidence indicates that strategic planning only has a forceful hand in Amsterdam. From an international perspective, this strategic planning belief also explains why market-driven or property-led development has hardly occurred on the waterfronts of either of these port cities.
To accommodate the forecasted growth of port business, the ports of Amsterdam and Rotterdam both aim to intensify the use of their existing territory (Port of Rotterdam 2012; Haven Amsterdam 2013). This, combined with the on-going transformation of the older parts of the port, is making the current interface between city and port an experimental zone for new land-use combinations, and an interesting laboratory for port-urban research.

While city planners seem to keep dominating the development of the interface in Amsterdam, the power balance in Rotterdam has unmistakably shifted in favour of the port authority due to its relatively large resource base. However, now that port users - like commodity traders and transhipment companies - in both port cities have involved themselves more emphatically in planning processes, it seems that the waterfront development process in both port cities are facing an important new challenge: the integration of existing port community interests into interface development schemes. Taking Hoyle's statement above to heart, such integration will play a crucial role in the continued evolution of the port city interface in the Netherlands.

\section{Acknowledgements}

The authors would like to thank the two anonymous referees and the editors for their feedback on earlier versions of this article. We would also like to thank Wendy de Hoog and Robert Pennings for making the illustrations. Usual disclaimers apply.

\section{Notes}

1. Vierde Nota voor de Ruimtelijke Ordening Extra (VINEX).

2. For a description, see also De Roo (2003, Chapter 7).

3. http://www.portofamsterdam.com/Eng/port/ physical-space/spatial-development-Minerva.html? highlight $=$ restructuring $\% 2 \mathrm{c} \% 20$ minerva $\% 2 \mathrm{c} \%$ 20port\%2c\%20area.

\section{REFERENCES}

Breen, A. \& D. Rigby (1996), The New Waterfront: A Worldwide Urban Success Story. London: McGrawHill. 
BRUtTOMESSO, R. (1993), Waterfronts: A New Frontier for Cities on Water. Venice: International Centre for Cities on Water.

DAAMEN, T.A. (2010), Strategy as Force: Towards Effective Strategies for Urban Development Projects. The Case of Rotterdam CityPorts. Amsterdam: IOS Press

DAAMEN, T.A. \& I. VRIES (2013), Governing the European Port-city Interface: Institutional Barriers on Spatial Projects between City and Port. Journal of Transport Geography 27, pp. 4-13.

DE Roo, G. (2003), Environmental Planning in the Netherlands: Too good to be true. From command and control planning to shared governance. Aldershot: Ashgate.

Dembski, S. (2013), Case Study Amsterdam Buiksloterham, the Netherlands: The Challenge of Planning Organic Transformation. Amsterdam: University of Amsterdam, AISSR programme group Urban Planning.

Ducruet, C., D. IEtri \& C. Rozenblat (2011), Cities in Worldwide Air and Sea Flows: A Multiple Networks Analysis. Cybergeo. Available at <http://cybergeo.revues.org/23603>. Accessed on 9 April 2016.

ESPO (2010), Code of Practice on Societal Integration of Ports. Brussels: European Seaports Organisation.

Fainstein, S. (2011), The Just City. Ithaca, NY: Cornell University Press.

Galland, D. \& C.J. Hansen (2012) The Roles of Planning in Waterfront Redevelopment: From Plan-led and Market-driven Styles to Hybrid Planning? Planning Practice and Reseach 27, pp. 203-225.

GEMEENTE AMSTERDAM (2013), Transformatiestrategie Haven-stad: Sterke Stad, Slimme Haven. Amsterdam: Gemeente Amsterdam (Projectgroep Haven-Stad).

Hall, P.V. (2007), Seaports, Urban Sustainability, and Paradigm Shift. Journal of Urban Technology14, pp. 87-101

Hall, P.V. \& W. Jacobs (2012), Why are Maritime Ports (Still) Urban, and Why Should Policymakers Care? Maritime Policy E Management 39, pp. 189-206

HARVEY, D. (1990), The Condition of Postmodernity: An Enquiry into the Origins of Cultural Change. Oxford: Blackwell.

HAVEN AMSTERdAM (2013), Zelfstandig Verstandig. Haven Amsterdam NV op Hoofdlijnen. Amsterdam: Haven Amsterdam NV.

Hayuth, Y. (2007), Globalization and the PortUrban Interface: Conflicts and Opportunities.
In: J. Wang, D. Olivier, T. Notteboom \& B. SLACK, eds, Ports, Cities, and Global Supply Chains, pp. 141-156. Aldershot: Ashgate.

HeAley, P. (2010), Making Better Places. London: Palgrave.

Hoppenbrouwer, E. \& E. Louw (2005) Mixed-use Development: Theory and Practice in Amsterdam's Eastern Docklands. European Planning Studies 13, pp. 967-983.

HOYLE, B.S. (2000), Global and Local Change on the Port-City Waterfront. Geographical Review 90, pp. 395-417.

JACOBS, W. (2014), Rotterdam and Amsterdam as Trading Places? In Search of the EconomicGeographical nexus Between Global Commodity Chains and World Cities. Tijdschrift voor Economische en Sociale Geografie 105, pp. 483-491.

Jacobs, W., H.R.A. Koster \& P.V. Hall (2011), The Location and Global Network Structure of Maritime Advanced Producer Services. Urban Studies 48, pp. 2749-2769.

Malone, P., ed. (1996), City, Water, Capital. London: Routledge

Marshall, R., ed. (2001), Waterfronts in Postindustrial Cities. London: Spon Press

MCCARTHY, J. (1996), Waterfront Regeneration in the Netherlands: The Cases of Rotterdam and Maastricht. European Planning Studies 4, pp. 545560.

Meyer, V. J. (1999), City and Port. Utrecht: International Books.

Milošević, M. (2014), Vraaggericht Sturen in de Ont-wikkeling van Merwe-Vierhavens Rotterdam (Ph.D. thesis, TU Delft).

Ng, A.K.Y., C. Ducruet, W. Jacobs, J. Monios, T. Notteboom, J-P. Rodrigue, B. Slack, K. TAM \& G. WilmsmeIER (2014), Port Geography at the Crossroads with Human Geography: Between Flows and Spaces. Journal of Transport Geography 41, pp. 84-96

NG, A.K.Y. \& A.A. Pallis (2010), Port Governance Reforms in Diversified Institutional Frameworks: Generic Solutions, Implementation Ssymmetries. Environment $\mathcal{E}$ Planning A 42, pp. 21472167.

Norcliffe, G., K. BASset \& T. HoAre (1996), The Emergence of Postmodernism on the Urban Waterfront. Journal of Transport Geography 4, pp. 123-134.

Notteboom, T., P. DE LAngen, W. JACObs (2013), Institutional Plasticity and Path Dependence in Seaports: Port Governance Reforms and Port 
Routines. Journal of Transport Geography 27, pp. 26-35.

OAKLEY, S. (2011) Re-imagining City Waterfronts:

A Comparative Analysis of Governing Renewal in Adelaide, Darwin and Melbourne. Urban Policy and Research 29, pp. 221-238.

OECD (2013), The Competitiveness of Global PortCities: Synthesis Report. Paris: Organisation of Economic Co-Operation and Development.

Ploeger, R. (2004), Regulating Urban Office Provision. A study of the ebb and flow of regimes of urbanisation in Amsterdam and Frankfurt am Main, 1945-2000 (Ph.D. thesis, University of Amsterdam)

Port of RotTerdam (2012), Havenvisie 2030. Port Compass: Direct the Future, Start Today. Rotterdam: Port of Rotterdam.

Priemus, H. (2001), Recent Transformations in Urban Policies in the Netherlands. In: D. HAUPTMANN \& A. GRAAFLAND, eds. (2001), Cities in Transition, pp. 388-403. Rotterdam: NAi/010 Publishers.

TAŞAN-KOK, T. (2010), Entrepreneurial Governance: Challenges of Large-Scale Property-led Urban Regeneration Projects. Tijdschrift voor Sociale en Economische Geografie 101, pp. 126-149.
TeISMAN, G.R. (1992), Complexe Besluitvorming: Een Pluricentrisch Perspectief op Besluitvorming over Ruimtelijke Investeringen. Den Haag: Elsevier.

VAN DER KnaAP, B. \& D. Pinder (1992), Revitalizing the European Waterfront: Policy Evolution and Planning Issues. In: B.S. HoYLE \& D.A. PINDER, eds., European Port Cities in Transition, pp. 153-175. London: Belhaven.

VERHOEVEN, P. (2006), Port Management Reform in Europe: Is There a Role for the EU? In: T. NOTTEBOOM, ed., Ports are More than Piers, pp. 35-56. Antwerp: De Lloyd.

Wiegmans, B.W. \& E. Louw (2010), Changing Port-city Relations at Amsterdam: A New Phase at the Interface? Journal of Transport Geography 19 , pp. 575-583.

Wigmans, G. (1998), De Facilitaire Stad: Rotterdams Grondbeleid en Postmodernisering. Delft: Delft University Press.

WITBRAAD, F. \& P. JORNA (1993), Waterfront Regeneration: The IJ Embankments Project in Amsterdam. In: J. BERRY, S. MGGREAL \& B. DEDDIS, eds., Urban Regeneration: Property Investment and Development, pp. 230-239. London: Spon.

WORLD BANK (2007), Port Reform Toolkit (2nd edn). Washington DC: The World Bank Group. 